\title{
Intestinal digestibility of protein and amino acid of ruminant feeds with the mobile nylon bag and in vitro digestion technique*
}

\author{
Q. Yue ${ }^{1}$, H.J. Yang ${ }^{1,3}$, Ch.Y. Xie ${ }^{1}$, X.B. Yao'and J.Q. Wang ${ }^{2}$ \\ ${ }^{1}$ Department of Animal Biology \& Physiology, College of Biological Sciences, \\ China Agricultural University \\ Beijing 100094, P.R. China \\ ${ }^{2}$ State Key Laboratory of Animal Nutrition, Institute of Animal Science, \\ China Academy of Agricultural Sciences \\ Beijing 100094, P.R. China
}

\begin{abstract}
The study was to provide the Chinese Feedbank with intestinal digestibility (Idg) of crude protein (CP) and AA for feedstuffs commonly used in China. The various AA of feedstuffs weren't synchronously digested, while a larger variation was found in the same AA between feedstuffs. The CP Idg estimated by mobile nylon bag technique in soyabean meal, cottonseed meal, peanut cake meal, rapeseed meal, rice bran, maize germ meal, wheat bran and lucerne hay were $0.964,0.813$, $0.950,0.826,0.586,0.793,0.679$ and 0.400 , respectively. It has a strong correlation with the value obtained by three-step in vitro procedure.
\end{abstract}

KEY WORDS: crude protein, amino acid, intestinal digestibility, ruminants

\section{INTRODUCTION}

According to the new protein evaluation systems, the protein value of a feed for ruminants is now commonly expressed as amino acids truly absorbed from the small intestine (Hvelplund and Weisbjerg, 2000). Currently, as the lack of intestinal digestibility (Idg) parameters of individual feedstuffs commonly used in China, Feeding Standard of Beef Cattle (Feng et al., 2005) assumed a constant value of 0.65

\footnotetext{
* Supported by the Beijing Municipal Nature Science Foundation and National Natural Science Foundation of China

${ }^{3}$ Correspoding author: e-mail: yang_hongjian@cau.edu.cn
} 
of rumen undergradable protein for concentrate, and 0.60 for roughage etc., which obviously sound much more recognized. The objective of this study was firstly, the choice of residuals of soyabean meal, cottonseed meal, peanut cake meal, rapeseed meal, rice bran, maize germ meal, wheat bran and lucerne hay after in situ nylon bag incubation was discussed for further Idg determination with the mobile nylon bag technique (MNBT). Secondly, apparent Idg of amino acids or CP was determined using both MNBT and the three-step in vitro procedure. Correlation of Idg between the two methods was further discussed for their reliability and applicability.

\section{MATERIAL AND METHODS}

Two steers (Simmental $\times$ Chinese Yellow cattle crossbreed) were fitted with a permanent flexibal ruminal cannula and a T-type proximal duodenal cannula. They were housed in individual stall and fed with the same amount of a standardized diet containing $4.2 \mathrm{~kg}$ Chinese wild rye day ${ }^{-1}$ and $4.8 \mathrm{~kg}$ concentrate mixture day ${ }^{1}$ which was equally offered at 08.00 and 20.00 .

The tested feeds included soyabean meal (SBM), cottonseed (CSM), peanut cake meal (PCM), rapeseed meal (RSM), rice bran (RB), maize germ meal (MGM), wheat bran (WB) and lucerne hay (LH). Dry matter and CP were determined according to AOAC (1999). The AA profiles were estimated by a HPLC system (Waters 26954, Waters Corporation, US). The in situ procedures applied to measure rumen disappearance and intestinal digestion were mainly as described by Hvelplund and Weisbjerg (2000). The three-step in vitro procedure was performed according to Calsamiglia and Stern (1995).

Ruminal degradation characteristics of $\mathrm{CP}$ and AA were calculated according to Ørskov and McDonald (1979) using PROC NLIN (SAS, 1999). The effective degradability (ED) was calculated using a rumen fractional outflow rate $(\mathrm{k})$ of 0.05 $\mathrm{h}^{-1}$. PROC GLM was used to analyse the differences between the disappearance rate (DR) at the rumen incubation time of 12,16 and $24 \mathrm{~h}$ and ED of CP or AA within feedstuff, with Duncan's multiple range test used for the comparison of means (SAS, 1999). The same procedure was used to analyse the differences within feed residue remaining after rumen incubation in Idg of CP and AA. The relationship between MNBT and three-step procedure digestibility was measured for linear regression using the PROC REG (SAS, 1999).

\section{RESULTS AND DISCUSSION}

The variation of CP was pronounced from $121.4 \mathrm{~g} \mathrm{~kg}^{-1} \mathrm{DM}$ in $\mathrm{LH}$ to $497.5 \mathrm{~g} \mathrm{~kg}^{1}$ DM in SBM. SBM and RB had a relatively high content of essential amino acids 
(EAA), and WB had a relatively low content. The proportion of Lys varied from 2.69

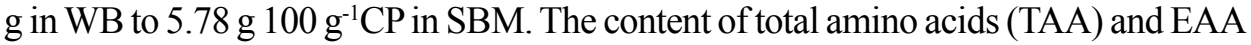
in SBM, CSM, WB and LH was higher than found by Taghizadeh et al. (2005) but EAA in LH. The individual EAA in SBM was lower than literature data presented by Harstad and Prestløkken (2000) except Ile. These differences might be due to different plant varieties, producing areas, processing, chemical analyse methods, etc.

The disappearance rate after rumen incubation for 12,16 and $24 \mathrm{~h}$ and effective degradability for CP, TAA, EAA, and non-essential amino acids (NEAA) were obtained, and the values of SBM were presented in Figure 1. It's obvious from our results, the DR after $24 \mathrm{~h}$ of rumen fermentation was much

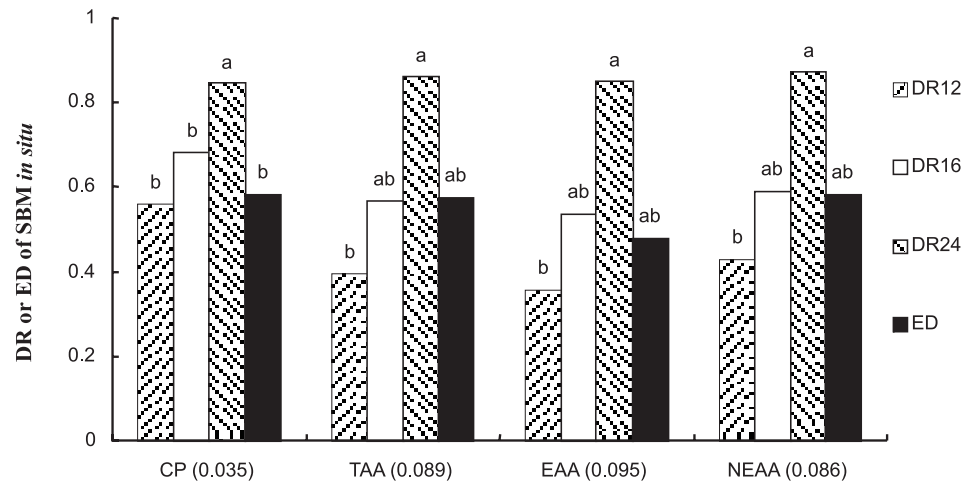

Figure 1. The in situ disappearance rate in rumen (DR) at the time of 12, 16 and $24 \mathrm{~h}$ and effective degradability (ED) of crude protein (CP), total amino acids (TAA), essential amino acids (EAA), non-essential amino acids (NEAA) using a rumen fractional outflow rate (k) of $0.05 \mathrm{~h}^{-1}$ for soyabean meal (SBM). The figures in parentheses represent standard error of means within a same class, and means in the same column within a class followed by different letter differ $(\mathrm{P}<0.05)$

higher than the values after 12 or $16 \mathrm{~h}$ of rumen fermentation and those values of ED, and the difference between the ED and DR after 12 or $16 \mathrm{~h}$ of rumen incubation was not significant except WB. Hence, for most feedstuffs the CP and AA profile in the residue of 12 or $16 \mathrm{~h}$ incubation time can be used to reflect the rumen undegraded $\mathrm{CP}$ and AA profile reaching the small intestine. Furthermore, Hvelplund and Weisbjerg (2000) pointed that incubation for $16 \mathrm{~h}$ could be used for all feeds at present, as this incubation time was believed to reflect the influence of rumen metabolism on the feed before passage to the intestine. For the standardization of the mobile nylon bag technique adopted in China, the choice of residuals of tested feedstuffs after in situ nylon bag incubation for $16 \mathrm{~h}$ was strongly recommended for further Idg determination of CP and AA.

The digestion of CP and AA in small intestine was calculated (Table 1) basing on the residue preincubated $16 \mathrm{~h}$ in rumen. The intestinal digestibility among feedstuffs varied considerably. $\mathrm{RB}, \mathrm{WB}$ and $\mathrm{LH}$, showing higher disappearance of $\mathrm{CP}$ and $\mathrm{AA}$ 
in the rumen, presented lower digestion in small intestine. Weisbjerg et al. (1996), who studied 15 different concentrates, indicated that the Idg of TAA was similar to that of CP in the residues. But it only agreed with SBM, PCM, RSM, RB and WB in our study. Therefore, using the Idg of $\mathrm{CP}$ to replace the values of TAA is problematic. Moreover, the assumed constant value of 0.65 of RUP for concentration, and 0.60 for roughage etc., adopted in Feeding Standard of Beef Cattle (Feng et al., 2005) cannot account for real supply of available amino acids in the intestinal tract for host animal.

Table 1. The apparent intestinal digestibility of crude protein (CP), total amino acids (TAA) and individual amino acids for the residue of feedstuffs after preincubated $16 \mathrm{~h}$ in the rumen estimated by the mobile nylon bag technique

\begin{tabular}{|c|c|c|c|c|c|c|c|c|}
\hline Sample $^{1}$ & SBM & $\mathrm{CSM}$ & PCM & RSM & $\mathrm{RB}$ & CGM & WB & $\mathrm{AH}$ \\
\hline $\mathrm{CP}$ & $0.964^{\mathrm{ab}}$ & $0.813^{\mathrm{k}}$ & $0.950^{\text {abcd }}$ & $0.826^{\mathrm{de}}$ & $0.586^{\text {cdef }}$ & $0.793^{f}$ & $0.679^{\text {efg }}$ & $0.400^{\mathrm{e}}$ \\
\hline TAA & $0.975^{\mathrm{ab}}$ & $0.889^{\text {cde }}$ & $0.949^{\mathrm{abcd}}$ & $0.867^{\text {bcde }}$ & $0.592^{\text {cdef }}$ & $0.858^{\mathrm{cd}}$ & $0.657^{\text {ghi }}$ & $0.581^{\mathrm{abcc}}$ \\
\hline Arg & $0.989^{\mathrm{a}}$ & $0.934^{\mathrm{a}}$ & $0.974^{\mathrm{a}}$ & $0.903^{\mathrm{ab}}$ & $0.724^{\mathrm{a}}$ & $0.914^{\mathrm{ab}}$ & $0.731^{\mathrm{bc}}$ & $0.471^{\text {cde }}$ \\
\hline His & $0.968^{\mathrm{ab}}$ & $0.884^{\mathrm{ef}}$ & $0.930^{\mathrm{d}}$ & $0.864^{\text {bcde }}$ & $0.579^{\mathrm{def}}$ & $0.853^{\text {cde }}$ & $0.699^{\text {cdef }}$ & $0.580^{\mathrm{abcc}}$ \\
\hline Ile & $0.951^{\mathrm{b}}$ & $0.882^{\mathrm{f}}$ & $0.949^{\mathrm{abcd}}$ & $0.871^{\mathrm{bcd}}$ & $0.629^{c}$ & $0.878^{a b c}$ & $0.725^{\mathrm{bcd}}$ & $0.634^{\mathrm{ab}}$ \\
\hline Leu & $0.968^{\mathrm{ab}}$ & $0.885^{\text {def }}$ & $0.951^{\mathrm{abcd}}$ & $0.878^{a b c}$ & $0.587^{\text {cdef }}$ & $0.884^{\mathrm{abc}}$ & 0.659 ghi & $0.607^{\mathrm{abc}}$ \\
\hline Lys & $0.978^{\mathrm{ab}}$ & $0.819^{\mathrm{k}}$ & $0.931^{\mathrm{cd}}$ & $0.863^{\text {bcde }}$ & $0.563^{e f}$ & $0.810^{\text {def }}$ & $0.749^{b}$ & $0.705^{\mathrm{a}}$ \\
\hline Met & $0.990^{\mathrm{a}}$ & $0.929^{\mathrm{a}}$ & $0.967^{\mathrm{ab}}$ & $0.922^{\mathrm{a}}$ & $0.727^{\mathrm{a}}$ & $0.927^{\mathrm{a}}$ & $0.785^{\mathrm{a}}$ & - \\
\hline Phe & $0.968^{\mathrm{ab}}$ & $0.914^{\mathrm{b}}$ & $0.957^{\mathrm{abcd}}$ & $0.873^{\mathrm{bcd}}$ & $0.572^{\mathrm{def}}$ & $0.874^{b c}$ & $0.670^{\mathrm{fgh}}$ & $0.613^{\mathrm{ab}}$ \\
\hline Thr & $0.981^{\mathrm{ab}}$ & $0.831^{\mathrm{j}}$ & $0.955^{\mathrm{abcd}}$ & $0.853^{\text {cde }}$ & $0.559^{\text {ef }}$ & $0.804^{\text {ef }}$ & $0.634^{\mathrm{hi}}$ & $0.458^{\mathrm{de}}$ \\
\hline Tyr & $0.975^{\mathrm{ab}}$ & $0.910^{\mathrm{b}}$ & $0.967^{\mathrm{ab}}$ & $0.902^{\mathrm{ab}}$ & $0.717^{\mathrm{a}}$ & $0.868^{\mathrm{bc}}$ & $0.690^{\operatorname{defg}}$ & $0.569^{\mathrm{abcc}}$ \\
\hline Val & $0.980^{\mathrm{ab}}$ & $0.891^{\text {cde }}$ & $0.947^{\mathrm{abcd}}$ & $0.864^{\text {bcde }}$ & $0.604^{\text {cde }}$ & $0.877^{a b c}$ & $0.665^{\text {fgh }}$ & $0.582^{\mathrm{abcc}}$ \\
\hline Ala & $0.972^{\mathrm{ab}}$ & $0.858^{\mathrm{g}}$ & $0.945^{\mathrm{bcd}}$ & $0.874^{\mathrm{bcd}}$ & $0.606^{\text {cde }}$ & $0.868^{\mathrm{bc}}$ & $0.623^{\mathrm{i}}$ & $0.589^{\mathrm{abcc}}$ \\
\hline Asp & $0.982^{\mathrm{a}}$ & $0.891^{\mathrm{cd}}$ & $0.959^{\mathrm{abc}}$ & $0.852^{\text {cde }}$ & $0.545^{\mathrm{fg}}$ & $0.847^{\mathrm{cdef}}$ & $0.633^{\text {hi }}$ & $0.615^{\mathrm{ab}}$ \\
\hline Cys & $0.982^{\mathrm{ab}}$ & $0.913^{b}$ & $0.950^{\mathrm{abcd}}$ & $0.855^{\text {bcde }}$ & $0.377^{\mathrm{i}}$ & $0.688^{\mathrm{g}}$ & - & $0.379^{\mathrm{e}}$ \\
\hline Glu & $0.983^{\mathrm{ab}}$ & $0.914^{\mathrm{b}}$ & $0.967^{\mathrm{ab}}$ & $0.878^{\mathrm{abc}}$ & $0.672^{b}$ & $0.884^{\mathrm{abc}}$ & $0.710^{\text {cde }}$ & $0.638^{\mathrm{ab}}$ \\
\hline Gly & $0.964^{\mathrm{ab}}$ & $0.850^{\mathrm{h}}$ & $0.861^{\mathrm{e}}$ & $0.858^{\text {bcde }}$ & $0.547^{\mathrm{fg}}$ & $0.800^{f}$ & $0.548^{j}$ & $0.510^{\text {bcde }}$ \\
\hline Pro & $0.970^{\mathrm{ab}}$ & $0.860^{\mathrm{g}}$ & $0.935^{\mathrm{cd}}$ & $0.817^{\mathrm{e}}$ & $0.479^{\mathrm{h}}$ & $0.804^{\text {ef }}$ & $0.579^{j}$ & $0.509^{\text {bcde }}$ \\
\hline Ser & $0.966^{\mathrm{ab}}$ & $0.840^{\mathrm{i}}$ & $0.929^{\mathrm{d}}$ & $0.837^{\text {cde }}$ & $0.508^{\text {gh }}$ & $0.831^{\mathrm{cdef}}$ & $0.568^{\mathrm{j}}$ & $0.468^{\text {cde }}$ \\
\hline SEM $^{2}$ & 0.009 & 0.002 & 0.008 & 0.014 & 0.014 & 0.016 & 0.011 & 0.041 \\
\hline
\end{tabular}

${ }^{1} \mathrm{SBM}$ - soyabean meal, CSM - cottonseed meal, PCM - peanut cake meal, RSM - rapeseed meal, $\mathrm{RB}$ - rice bran, MGM - maize germ meal, WB - wheat bran, LH - lucerne hay; ${ }^{2} \mathrm{SEM}$ - standard error of the mean; ${ }^{\mathrm{a}-\mathrm{k}}$ means within a column with different subscripts $\operatorname{differ}(\mathrm{P}<0.05)$

As the limiting amino acid, Lys in SBM, WB and LH had a higher Idg than TAA as well as most other individual AA, but in the other 5 feedstuffs it had a lower Idg. In the study by Taghizadeh et al. (2005), which included 10 different feedstuffs, it was shown that Lys Idg was higher than TAA Idg except for maize grain, fish meal and barley grain. The lowest Idg of Lys was observed in RB, a feedstuff that has some trypsin-inhibitor (TI). The TI can inhibit the action of trypsin which is an endopeptidase to hydrolyse only Lys or Arg bonds. 
In general, the digestibility obtained from three-step procedure was lower than corresponding data obtained via MNBT. That might be relative to protein digestion that occurs in the large intestine. A much higher RSM digestibility examined with MNBT might attributive to the antinutritional factors in RSM.

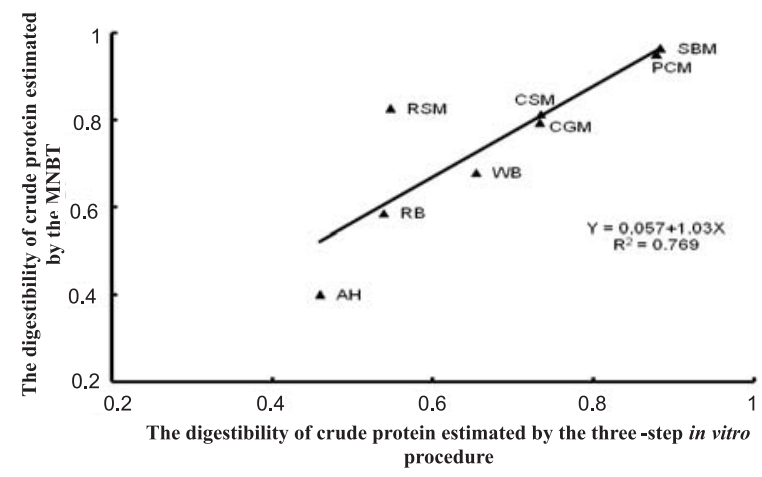

Figure 2. Relationship and linear regression equations between CP digestions for the residuals of soyabean meal (SBM), cottonseed meal (CSM), peanut cake meal (PCM), rapeseed meal (RSM), rice bran (RB), maize germ meal (CGM), wheat bran (WB) and lucerne hay (LH) after preincubated in the rumen for $16 \mathrm{~h}$ measured by the mobile nylon bag technique (MNBT) and the three-step in vitro procedure

The relationship of digestibility between MNBT and three-step procedure was best described by the linear regression equation:

$$
\mathrm{Y}=0.057+1.03 \mathrm{X}, \mathrm{R}^{2}=0.769, \mathrm{P}=0.004
$$

where: $\mathrm{Y}$ represents Idg estimated by MNBT, and X represents the Idg with threestep technique.

Furthermore, Stern et al. (1997) measured results of three-step procedure with in vivo intestinal protein digestion and found a high correlation $\left(\mathrm{R}^{2}=0.91\right)$. Therefore, the three-step technique might be a rapid, reliable procedure for evaluating intestinal digestion of proteins in ruminants.

\section{CONCLUSIONS}

For the standardization of the mobile nylon bag technique adopted in China, the choice of residuals of tested feedstuffs after in situ nylon bag incubation for $16 \mathrm{~h}$ was strongly recommended for further intestinal $\mathrm{CP}$ and AA digestibility determination. Using an assumed constant or the digestibility of $\mathrm{CP}$ to replace those of TAA or individual AA is problematic for individual feeds in feed evaluation for 
new protein system. The three-step in vitro technique might be a rapid, reliable procedure for evaluating intestinal digestion of proteins in ruminants.

\section{REFERENCES}

AOAC, 1999. Association of Official Analytical Chemists, Official Methods of Analysis. 16th Edition. Washington, DC

Calsamiglia S., Stern M.D., 1995. A three-step in vitro procedure for estimating intestinal digestion of protein in ruminants. J. Anim. Sci. 73, 1459-1465

Feng Y.L., Wang J.Q., Yang H.J., Mo F., Wei H.Y., Hang Y.X., Feng D.Y., Wang Z.H., Gong Y.S., Li S.C., 2005. Feeding Standard of Beef Cattle. China Agriculture Press, Beijing

Harstad O.M., Prestløkken E., 2000. Effective rumen degradability and intestinal indigestibility of individual amino acids in solvent-extracted soybean meal (SBM) and xylose-treated SBM (SoyPass ${ }^{\circledR}$ ) determined in situ. Anim. Feed Sci. Tech. 83, 31- 47

Hvelplund T., Weisbjerg M.R., 2000. In situ techniques for the estimation of protein degradability and postrumen avaliability. In: D.I. Givens, E. Owen, R.F.E. Axford, H.M. Omed (Editors). Forage Evaluation in Ruminant Nutrition. CABI Publishing, Oxon, pp. 233-258

Ørskov E.R., McDonald I., 1979. The estimation of protein degradability in the rumen from incubation measurements weighted according to rate of passage. J. Agr. Sci. 92, 499-503

SAS, 1999. Statistical Analysis System User's Guide: Statistics, Version 8.2 Edition. SAS Institute Inc. Cary, NC

Stern M.D., Bach A., Calsamiglia S., 1997. Alternative techniques for measuring nutrient digestion in ruminants. J. Anim. Sci. 75, 2256-2276

Taghizadeh A., Mesgaran M. D., Valizadeh R., 2005. Digestion of feed amino acids in the rumen and intestine of steers measured using a mobile nylon bag technique. J. Dairy Sci. 88, 1807-1814

Weisbjerg M.R., Hvelplund T., Hellberg S., Olsson S., Sanne S., 1996. Effective rumen degradability and intestinal digestibility of individual amino acids in different concentrates determined in situ. Anim. Feed Sci. Tech. 62, 179-188 